of emotional disturbance. Neither alone is enough; both are necessary. In the elucidation of so-called growing pains the doctor needs to consider much more than the pains alone.

1 Apley, J., Proceedings of the Royal Society of Medicine, 1970, 63,

2 Apley, J., Proceedings of the Royal Society of Medicine, 1958, 51, Øster, J., and Nielsen, A., Acta Paediatrica Scandinavica, 1972, 61, 329.

4 Brenning, R., Acta Societatis medicorum Upsaliensis, 1960, 65, 185. 5 Naish, J. M., and Apley, J., Archives of Disease in Childhood, 1951, 26, 134.

6 British Medical fournal, 1970, 4, 758

7 Øster, J., Danish Medical Bulletin, 1972, 19. 72.

8 Apley, J., and MacKeith, R. C., The Child and His Symptoms, 2nd edn. Oxford, Blackwell, 1968.

\section{Environment for Mental Patients}

The future institutional care of the mentally disordered still hinges on the to-be-or-not-to-be of the 1962 Hospital Plan. Official pronouncements since then would seem to indicate that in some measure at any rate the plan will be realized and the emphasis will shift from care in the mental hospitals to care in the community. Of crucial importance in this context is the establishment of psychiatric units in the district general hospitals, which would be expected to cope with all the adult psychiatric problems in their catchment populations.

Apart from the desirability of such units-and they have recently come under criticism ${ }^{1}{ }^{2}$-it is clear that if they are to be established the planning of them and of any other buildings that will be required should be undertaken with care so as to minimize the number of mistakes inevitable in such a transformation. A report just published by the Society of Clinical Psychiatrists, written by Dr. C. P. Seager, ${ }^{3}$ is therefore timely. It is a review of the literature and despite one or two omissions it is to be earnestly recommended to those people on whose shoulders the responsibility of spending vast sums of public money, not to mention the welfare of many thousands of sick people, will lie.

The report traces briefly the history of specialist design of psychiatric units, using some British but in the main American sources from the late nineteenth century to modern times. The ever changing scene in contemporary psychiatric practice, probably more apparent than real in fact, is reflected in the variety of plans that have emerged, some of them frankly contradictory. One planner even feels obliged to emphasize the need for built-in obsolescence. This is understandable when the number of variables to be taken into account are considered. The estimated bed requirement per thousand population, for example, varies as widely as does the estimate of the ideal size of the psychiatric unit itself. Too small a unit, it is argued, cannot provide a full range of facilities; too large a unit is apt to be impersonal, runs a counter argument. Some planners pay attention to the needs of security, whereas others regard locked doors and other symbols of custodialism as an outrage and as archaic as the strait waistcoat. What is all too evident, as the report heavily underlines, is "a surprising dearth of valid recearch concerning the effect of physical environment on behaviour."

It is right in the light of recent scandals that the report pays special attention to the institutional needs of the men- tally subnormal. Here the report includes the reflection that the problem must be divided between those people requiring treatment as such and those whose primary need is care. The latter fall more into the realm of the educationalist and sociologist and should be coped with outside the hospital system. For people requiring treatment the plans surveyed range from the purely mechanistic concerned with adequate cleanliness and control of odour to the effects of the environment on the psyche of emotionally disturbed and mentally subnormal children. It is at this point that one omission in the literature surveyed in the report is particularly apropos. In 1971 the Department of Health and Social Security published a sensible and humane document ${ }^{4}{ }^{5}$ based on a study by a team of architects, planners, quantity surveyors, and engineers assisted by medical and nursing advisers from the Department. Its purpose, as Sir Keith Joseph, Secretary of State for the Social Services, wrote in a foreword, was "to provide architectural advice on the immediate problems of overcrowding and poor environmental conditions in our existing hospitals for the mentally handicapped." A second omission, even more important in a historical sense, is a reference to the work of our own John Conolly, ${ }^{6}$ an innovator and visionary, who as long ago as 1847 published a blueprint of the model mental hospital. His suggestions for the institutional care of the mentally disordered of any kind are as fresh and as brimful of humanity and good sense today as they were well over a century ago.

\footnotetext{
1 Tripartite Committee (Royal College of Psychiatrists, Society of Medical Officers of Health, and British Medical Association), The Mental Health Service after Unification. London, B.M.A., 1972. British Medical fournal, 1972, 3, 2.

3 British Medical fournal, 1972, 3, 2 . Architecture. Society of Clinical Peager, C. P., Psychiatry and Architecture. Society of Clinical
Psychiatrists, 1972. (Information from its Hon. Secretary, Department of Clinical Research, Crichton Royal Hospital, Dumfries, Scotland.)

Department of Health and Social Security, Buildings for Mentally Handicapped People. London, H.M.S.O., 1971

British Medical fournal, 1971, 3, 131

6 Conolly, J., The Construction and Government of Lunatic Asylums and Hospitals for the Insane, introduction by $\mathrm{R}$. Hunter and Ida Macalpine. First published 1847. London, Dawsons of Pall Mall, 1968.
}

\section{Immunological Control of Schistosomiasis}

The medical profession is often blamed for having created the population explosion in the developing world. The blame is apt to fall especially on those members of it who have carried out successful programmes for the control of disease. But the population explosion began long before any major public health measures were initiated, and it continues at much the same rate in areas where little is being done as in areas where there have been intensive control programmes. The main factors determining the increase of population in the tropics have been improvements in social and economic development, and especially the developments in agriculture that ensure adequate food supplies. Improved methods of cultivation, the expansion of irrigation, and the introduction of high-yielding crops have produced the "green revolution" and the population explosion. There are more people but they are not necessarily healthier.

Many parasitic and vector-borne diseases are becoming more prevalent as a result of the changes in agricultural practices and the increased density of the population. In 